\title{
11 Police, rural policing, and community safety
}

One reason this chapter is devoted to rural policing is the difference in police work and organization. More than 40 years ago, Cain (1973) highlighted the distinctiveness of rural policing, with its isolating and lonesome nature, and the dependence on one's neighbors and community within which the police lived. Rural crime issues are very different nowadays from those in the 1970s, and certainly rurality is a complex mix that imposes new demands on policing that go beyond issues of remoteness and isolation. Policing is no longer a job for the public police force only. Yet "( $t$ )here has always been, and still is, a difference between police work and organization in urban and rural areas" (Furuhagen, 2009, p. 13)

Mawby (2011) suggests that in many countries only a small proportion of policing is carried out by police officers especially trained by the central or local government. Alternative policing has not emerged at pace with this change or evenly distributed across or within countries. This chapter starts with an international overview of what the police have been, with particular focus on the historical development of the rural police as an institution. This is an important subject, as Mawby and Yarwood (2011, p. 1) suggest "studies of rural policing have fallen off the edge of many research agendas." This chapter also provides a detailed history of the development of policing in Swedish rural areas and discusses examples of the contemporary daily work of police with crime, crime prevention, and community safety, focusing on Sweden. Then, the chapter ends with a discussion of future challenges for policing in the Swedish countryside, as the commodification of policing has become a reality and the police organization is being centralized.

In this book, the term police refers to the civil force of a state responsible for the detection and prevention of crime and the maintenance of public order. In terms of actions, "police" is often associated with more traditional policing, that is, mostly reactive activities, such as patrol and direct reactions to the crimes and/or infractions being committed. Police have also been associated with proactive activities aimed at crime control as well as perceived safety. Policing is a broader concept that may include more than the police, often with the involvement of multiple actors, public and private ones, and citizens, all aimed at safety governance. Also referred to as community policing, it is more proactive than the 
traditional policing work of patrol. As suggested by Yarwood (2014), "community policing" usually refers to the efforts of various state, volunteer, and private agencies to police particular places in partnership with one another. Whilst police actions are typically dedicated to specific geographic areas in their jurisdiction, policing may have less distinctive territorial boundaries, as actors are not necessarily bound on a territorial basis.

\section{Police in rural areas: an international perspective}

The word police comes from the Greek words polis, meaning city or state, and politeia, management. The original meaning was the city administration or art of government. The modern police, a more "organized" police as we know them, are a relatively new phenomenon. They emerged with the development of communities where there was a clear power structure in the form of royalty or later, with independent administrative bodies. In Sweden, for example, the modern police developed in the 1800s and early 1900s as a result of industrialization and the growing need for control in cities that produced new and greater problems of order and crime. As Furuhagen (2009) states, police in a broader sense has a much longer history and is perhaps a phenomenon as old as humanity itself.

In the Middle Ages, and even in the modern era, the police played a varied role. In Sweden, police was a collective term for all public activities except the church; that is, to denote the part of the "domestic" and local management in charge of maintaining order and safety, practically everything that related to social, political, and economic life but, of course, did not have today's organization, with police departments and corps. Originally the police depended on individuals who shared the burden of ensuring collective safety. In small medieval towns, night watchmen alternated shifts monitoring the city and arresting criminals and beggars. In the countryside, peasants were assigned different roles, of village guard or parish constable. They could then also get other jobs in the local community and they worked occasionally as local agents or representatives of the king, that is, state power. Nowadays, the police reflect the state's monopoly on violence and are an institution responsible for order and security within the country (Furuhagen, 2004, 2009).

The way rural areas are policed nowadays is also a result of different traditions in policing. There are two accepted police traditions: one that follows the Anglo-Saxon model, which has its roots in England and in the United States, and the other, the continental police tradition, which prevailed in France, Italy, Germany, countries in southern and central Europe, and, to some extent, Canada. For a detailed description of Canada's and the United States' structure for rural policing, see Donnermeyer, DeKeseredy, and Dragiewicz (2011) and also later in this chapter.

The Anglo-Saxon model is characterized by decentralization and has been built on community-based and civil forms of policing with constables and guards, often unarmed. In the United States, systematic study of urban and small-town policing was almost nonexistent before the 1970s (Payne, Berg, \& 
Sun, 2005). Although studies were performed after that, researchers suggest that they are often descriptive and "atheoretical," with very limited attempts to link police structure and rural social structure (Donnermeyer et al., 2011; Weisheit, Falcone, \& Wells, 2006). These authors suggest that the absence of research is attributable to the fact that is may be difficult to obtain an acceptable sample size of events in small municipalities. Moreover, rural residents as well as police may be less likely to accept strangers and share information with outsiders, making it difficult to conduct research in rural areas.

The continental police tradition derived originally from France, which created a gendarmerie, that is, armed state police on horseback, in rural areas as far back as the sixteenth century. The French police developed much stronger links with armed forces and was heavily armed. According to Furuhagen (2009), the continental police is deemed to have been, and probably still is, less civic-oriented than the Anglo-Saxon police, which is closer to the people, more service-oriented and less authoritarian. The Swedish police have been influenced in varying degrees by both traditions. The Swedish police's historical roots are local, but the state's growing involvement has been a common thread in its historical development. The next section reviews rural and small-town policing in the United States, Canada, the United Kingdom, and Australia as background for the Swedish case.

\section{Glimpses of rural policing in the United States, Canada, the United Kingdom, and Australia}

The most comprehensive research on rural and small-town policing in the United States was conducted by Weisheit and colleagues (Falcone, Wells, \& Weisheit, 2002; Weisheit, Wells, \& Falcone, 1994). Payne et al. (2005) report that they found that rural and small-town police departments tend to emphasize crime prevention and service activities, whereas those based in large cities focus on enforcing law and controlling crime through arrests. They also found that policing styles in rural areas largely reflect the relationship between the police and the community. Moreover, rural officers are expected to carry out a wider range of tasks than their urban counterparts do, because other social services are either nonexistent or too remote to provide timely service. Moreover, like their urban counterparts, rural police have to adapt their strategy and tactics to meet the needs of their communities (Cordner \& Scarborough, 1997). Where tax bases are small, rural police departments are likely to be seriously understaffed and without important resources (Weisheit et al., 1994).

The rural setting has particular features shaping both crime and policing (Weisheit et al., 1994). Weisheit et al. (1994) give an example of what this means in the North American context. Although rural individuals are more likely to own guns, they are less likely to use guns in committing a crime. Gun ownership is much more prevalent in rural areas, where more than double the number of residents own guns than their urban counterparts. Nowadays, of the United States' estimated 13.7 million hunters, 18 percent reside outside metropolitan areas and 3 percent in big cities (Pompa \& Ganier, 2013). 
More recently, another face of rural areas in North America was presented by Donnermeyer et al. (2011). They highlight the complexity of rural communities in the United States and Canada and how it creates specific challenges for the police. On one hand, some of these rural areas are examples of the idyllic rural; on the other hand, some suffer from a number of problems, such as persistent poverty, depopulation, and youth drug addiction. They suggest that a way to understand the plurality of rural policing is to assume that there are several communities within a community that vary over time and space. Within these rural communities are various kinds of social orders that interplay with the formal structures of policing and deal with different types of crimes in different ways. The authors add that:

understanding policing practices in the rural context continue down a path of testing specific actions but without ever considering macro-level forces that place strong parameters for the ways in which rural communities, peoples and police can change and work together in more effective partnerships.

(Donnermeyer et al., 2011, p. 31)

In Britain, developments in policing have moved toward reactive policing, and many local police stations have been closed. Such changes are based on policing and governance at various levels as stipulated by the Crime and Disorder Act 1998. Economization in services in rural areas especially is argued to have affected some municipalities more than others, as policing has become less visible. In contrast, there have emerged in the 1990s local policing schemes based on volunteerism and community involvement. Farm Watch (FW) has been implemented across rural areas, its success in large part attributable to local police and partnership initiatives that support and maintain such initiatives. By the end of the decade, partnership initiatives had a firm place in government policy. Rural crime governance has changed in parallel with an increased emphasis on risk-based strategies that identify and police crime "hot spots" from the national to local levels, thus demoting crime in rural areas. Within the most rural regions, urban areas do exist, and these attract the bulk of available funding (Fyfe, 1995; Jones \& Phipps, 2012; Yarwood, 2011). Mawby (2011) suggests that a policing mix has characterized community policing in rural areas in the past 20 years, through the expansion of private and state agencies involved in policing as well as volunteers and police ancillaries. The number of special constables relative to regular officers is greater in rural areas and, according to the author, has remained constant over the years despite the expansion of private and state agencies involved in policing.

In a recent study in rural Scotland, Fenwick, Dockrell, Roberts, and Slade (2012) also found that the challenges of rural police include large territorial distances, limited access to resources for support, unique community expectations, and role conflicts experienced by police officers in the social dynamics 
of rural communities. In these circumstances, officers learn to balance being part of the community with carrying out their policing duties, or balance policing "by the book" with community expectations. To maintain legitimacy with the community, police need to respond to and resolve minor quality of life issues. Participants suggest that this practice increases the visibility of the police and provides opportunities to gather intelligence on community activities. Fenwick et al. (2012) used focus groups to find out the unique demands on police officers following a community policing model. They found, for instance, that evidence-based practice for policing does not fit the demands of rural communities, as they present special challenges to police.

Barclay, Scott, and Donnermeyer (2011) report on Australian cases of community policing in a country where the region plays an important role in policing. To start with, the organization of policing in Australia is different from both the United States and the United Kingdom. The organization practices and laws are determined more on a regional basis in Australian states and territories, each of which is policed by a single organization that is centrally controlled. These areas are divided into regions, then police districts, and then police stations. Some rural communities are served by officers located in neighboring towns, with officers working between communities. Community policing defines important aspects of the role of the police, under the localistic model. Local police officers are expected to become part of the community even if it compromises objectivity. This model also has disadvantages, namely that certain groups or activities become over-policed and others under-policed. Paradoxically, as a result the model may also favor certain groups and sectional interests (Barclay et al., 2011). This may support what a more critical account of this model states: "Some communities are more willing and able to help themselves and it is an irony that those in the need of most help are unlikely to benefit from self-help initiatives" (Yarwood, 2014, p. 6).

Sweden has a long tradition of local policing, but this does not mean that it has always been decentralized. Up to the mid-1960s, Sweden had a decentralized organization (see Table 11.2, later in the chapter). Later it became more driven from the center. In the 1980s, a debate about strong governmental intervention and centralization affected many sectors of society, including the police. This development also followed trends in practices in the United Kingdom and elsewhere focused on community-based policing in Sweden. Crucial for this decentralized policing model was the 1996 national program for crime prevention, in which local police forces were central actors (Ceccato \& Dolmén, 2011). Local partnerships meant that part of the responsibility of crime control and prevention was placed on the shoulders of civil society (Yarwood \& Edwards, 1995) with public engagement in different levels and initiatives. This collaborative model became - and is still regarded as - important to successful crime prevention. The next section discusses the origins of modern policing, up to current developments, with a focus on rural areas. 


\section{Police and policing in Sweden: focus on rural areas}

\section{From its origins to modern policing in the $1990 \mathrm{~s}^{1}$}

The Swedish police authority's earliest origins were in rural areas, where early forms of policing likely worked in the same way as in other countries, namely the local community itself was responsible for maintaining order. It was with the nascent monarchy that pre-modern police service began to take its current form. The king's bailiffs worked in the Middle Ages with tax collection and other details of the administration but also had overall responsibility for local law and order (Sjöholm, 1941). Already in Viking times, order and law had territorial features. According to Furuhagen (2009), when Sweden was Christianized (between the eighth and the twelfth centuries), the country was divided into parishes, each one led by a priest who met with the male farmers at parish meetings to discuss local affairs, including order in the parish, such as conflicts between neighbors or problems with rowdy youngsters. To maintain order in the parish, the priest was assisted by "six men," who were elders elected or appointed by the male farmers in different parts of each parish. They would keep a close eye on local order, helping to mediate conflicts and reporting to the priest on problems of order and neglect in their villages.

It was only in the early seventeenth century that the monarchy took over and governors in each county were given the ultimate responsibility for law and order. The crown bailiffs primarily handled tax collection in their districts but they also continued to watch over law and order and prosecute crime. In practice, these tasks were handled at the local level largely by the sergeants who served under each bailiff. In addition to police-like tasks, a bailiff could act as the representative of the state in the role of "prosecutor" in some cases before district courts (lower courts in rural areas). Police chiefs were not police officers in today's sense; they were a mixture of police, tax official, and prosecutor at the lowest level. Police chiefs remained until the early twentieth century when, through a reform, they were replaced by country fiscals that basically had the same function as early sheriffs (a mixture of police, tax official, and prosecutor at the lowest level) but also had more skilled tasks (e.g., responsibility for the seizure of taxes, fees, and fines and keeping an eye on trade and industry, transport and communications, fire protection, and construction). Under the fiscals, in each rural village there were fjärdingsmän, or constables, elected or appointed in the local community. In practice, these were often farmers or other people in the parish who often served part-time as police.

During the second half of the $1800 \mathrm{~s}$, it became clear that policing in the Swedish countryside was inadequate. Cities and market towns, with concentrations of many people brought by, for instance, train stations, mills, and industries, required officers devoted exclusively to police work. In the latter nineteenth century, urban communities would hire a police superintendent and, if necessary, additional police personnel. In the early twentieth century, rural police still were not considered satisfactory, despite state funding for hiring extra police. Although 
there were no military police, a mounted police combined with county detectives and reserve officers was started, half financed by the state, half by counties or municipalities. According to Furuhagen (2009), mounted police had already been implemented by several counties and were called the "county police" because they were employed by the county councils. In 1920, there were 2,789 constables throughout Sweden, but only 325 of these had full-time duties. Also, they were distributed irregularly across the country, as only 383 policemen served outside the cities. At the local level, police handled tasks along with sergeants, constables, and, later, extra officers.

There were large differences between urban police forces and police in rural areas as well as between various municipalities and between towns. In the capital, Stockholm, police also had a decentralized organization. The city was divided into several districts with local police stations. Each district was headed by a commissioner, who had several detectives and a large number of ordinary constables under him. They spent most of their time patrolling on foot. Crime prevention was limited, as the emphasis was on maintaining order in a broad sense.

In 1925, a more centralized police model came into force and was supported by several sectors of society, especially police officers. Police remained essentially a municipal concern, but the state could control a local police organization. This meant that national police legislation ensured police officers' employment and working conditions, with uniform rules for wages, disciplinary punishment, and dismissal. A school was the means for centralizing training which, until then, had been spread across the country and, by today's standards, had been short and inadequate. Furuhagen (2009) reports police wages were low, especially in rural areas and small towns, where the work day was long and hard. One problem of local police had been that officers could be arbitrarily dismissed with no independent investigation. The consequences of the Police Act 1925 were largely a codification and homogenization of police work. The local connection remained strong for many small police precincts, which had considerable freedom in organizing police work. Rural areas often had only a lone constable who, in practice, was busier collecting taxes and performing sundry tasks than officially assisting in police work.

Furuhagen (2009) adds that the Police Act 1925, unlike the current Police Act, did not contain any declarations of principles that police should prevent crime. There was also no discussion about police presence in the local community, which might suggest that in practice it was not a problem and not a concern because police and police work were already strongly rooted in the local community, especially in rural areas and small towns, where much of the population lived at that time. According to Furuhagen, this reform was positive but not enough to improve and adapt the police to society's needs. The problems were mainly in rural areas, where the military had to step in. A state police, which complemented the municipal police, was established in 1932. One of the main motivations for the founding of the state police was demonstrations in 1931 when the military shot and killed five civilians. However, the shortcomings of 
the existing municipal police organization were numerous. The main problem was that there were too many precincts and they were too small. In 1944, there were more than 1,600 precincts (of which 123 cities and 57 towns), and rural areas had many districts with only one or two police officers. Ten years later, there were 854 precincts, and in the early 1960s there were 554 . However, many districts had yet to get police officers to work satisfactorily: 70 percent of the districts had fewer than 10 police officers, some had only two. There was an increasing need for coordination over large geographical areas, particularly cooperation between police in rural areas and adjacent towns.

Personal and professional anecdotal evidence from police officers shows that the nationalization of the police meant additional resources, especially cars and other technical equipment, but also more bureaucracy and paperwork. There was now also greater consistency. In the meantime, municipal resources and circumstances for conducting effective policing still varied much between precincts. Technological developments contributed to the centralization of the police. The technology also favored a reactive approach (Furuhagen, 2009). Car patrols in the 1960s led to "alienated" police practices focused largely on event-driven emergency operations and neglect of contact with the community, because car patrolling was considered to have a deterrent effect on crime. There was an expectation that as police cars were constantly in motion, people would get the impression that the police were present everywhere. The debate about the dangers of a state police continued after nationalization. Some sectors of society alleged that the police in a centralized state could be a threat to democracy. In 1975, a police investigation led to reforms of the Swedish police in the 1980s and paved the way to a centralized model in the 1990s. With urbanization, police workloads not only increased in volume but also became more diverse. The decentralization of the police was thought necessary for the institution to adapt to more complex patterns of living and working that were emerging in larger cities at that time. This was followed in the 1980s by stronger citizen influence, as local police boards got more power to make decisions and manage their business, in terms of greater control over resource allocation. Police training also changed: the theoretical portion was expanded and contained more social and behavioral sciences. In practical everyday work, the reform advocated commitment to community policing, in which contact with the public increased while car patrols for prevention were to be avoided. During the 1990s, the reform of the Swedish police continued in the direction it began in the 1980s but faced numerous challenges as community policing reform demanded new resources that were reduced by the economic crisis of the early 1990s.

\section{Recent developments in Swedish rural policing: 1990s onwards}

As in other Western countries, in Sweden the police have undergone several transformations during the last 20-30 years. The two most important changes are the pluralization of actors exercising policing (from the hegemonic role of the police to a plethora of actors) and commodification of certain services and activities, with the expansion of private sector to traditional police roles. 
In rural areas, private security companies have gained legitimacy through explicit recognition of the state, as policing models become more local-oriented. Hence, these companies operate partly in combination with other public authorities and perform legitimatized functions of security governance. In 2005, 30 percent of Swedish municipalities conducted activities that fall within the responsibilities of the police (Thelin \& Svantemark, 2005). At the same time, one-third of municipalities employed private sector organizations to perform police patrols (Kommunaktuellt, 2002). This development is discussed in more detail in the following.

The "renewal bill 1989-1990" was the direct prelude to community police reform with the paper Alla vårt ansvar. The bill also suggested that most police officers be generalists, "overall police," meaning that they should be locally based officers responsible for all types of police work (criminal investigations, call-out service, crime prevention efforts). The reform was aimed at strengthening citizens' influence on crime prevention, which was considered the best way to deal with crime. Community policing would evolve to become the foundation of police activities framed by 21 police authorities (see Table 11.2, later in the chapter). The inspiration came from British and North American models such as community policing and problem-based policing. The idea was that the police should have stronger roots in the citizenry. Police work should have more contact with schools, social care, local organizations, and other agencies in the community (a predefined geographic area). Police work should also focus more than before on preventing crime. This would be achieved primarily through a systematic approach and problem-oriented policing in which police officers with good local knowledge would gather intelligence about crime and its prevention themselves. However, how many of these principles were actually put into practice?

It is clear the extent to which policing reform was not implemented in accordance with the government's intentions (Furuhagen, 2009). Several reasons obstruct the application of the model in practice. First, the reform was implemented gradually and at different times for different parts of the country. Some police authorities began to change their activities already in 1993, while others took until the late 1990s. In 2000, according to the National Police Agency, only 40 percent of all local police officers were considered "working with community policing," which was not enough to ensure plans for local policing. Second, the reform coincided with harsh economic times. Recruitment was limited. Only 20 percent of police officers were working as generalists in the 2000s, leading to the conclusion by the National Crime Prevention Council that community policing reform was not fully developed by then. Moreover, the introduction of the position of länspolismästare (chief commissioner of a county police department) was another form of centralization, according to Furuhagen (2009). The change meant the regional police chief was no longer part of the provincial government's organization but rather head of one of the county's police departments. In 1994, there were still 118 police regions, nearly the same number as in 1965. In 1998, there were only 21 police regions, one in each county. Furuhagen also quotes several researchers in Sweden who suggest that centralization - and not community policing - have characterized the police 
during the early 2000s. These researchers add that the reform led to a change in the organization alone and not in the orientation of policing services. Centralization was somehow obligatory because, as Sweden entered the European Union, better coordination at national and international levels would lead to centralization of certain routines. One example has been the need to merge the data from 21 police areas into single biometric information. By the mid-2000s, a survey (Kommunaktuellt, 2002) showed that half of the municipalities thought community policing worked poorly, and one-third of the municipalities employed private patrols to perform police-like work.

The political assessment was that the community policing reform would be implemented but that the police would get some new resources. However, funding for community policing reform was complicated by an acute crisis in public finances in the early 1990s. The initial idea was that there should be about 30 police officers in every community policing area, where there would be about 30,000 inhabitants; in other words, one police officer per 1,000 residents. The police were forced to cut the budget just as other public authorities were, resulting mainly in reduced staff numbers. Note that in the period 1986-2000, the number of police officers decreased (Table 11.1). Since the early 2000s, several community policing areas have merged.

Furuhagen (2009) indicates that the number of civilian employees decreased by 30 percent between 1993 and 2000. Police staff were not affected as much, but recruitment by the Police Academy stopped for three years in the mid-1990s. This trend in the police follows the overall national trend in employment by public sector entities during the 1990s (Brandt \& Westholm, 2008). The number of employees per citizen dropped significantly in 1993 and then increased again. This shift has occurred in small municipalities as well as large ones. The cause of these fluctuations appears to have been weaker public finances in the early 1990s. At the same time, technological and organizational changes during the decade made possible a reduction in the number of employees, reducing in particular the need for unskilled workers.

The sharp increase in the number of police officers reflects the recent government targets of having 20,000 police officers in Sweden. The number of candidates admitted to police training each year is based on this goal. The total number of police officers a police force may be assigned depends mostly on population and crime levels. Mapping police officers per municipality can be misleading. This is not a particularly useful measure, because a "police station" in a municipality may serve only parts of the municipality (in the south) or several neighboring municipalities (in the north). Obviously, not all police employees are officers, and administrative personnel account for a large part. The latter group has steadily increased, by 36 percent from 2000 to 2012 (from 6,205 to 8,457 employees). The Swedish National Police publish the number of police out of the 21 regional police forces, but the regional police authorities determine where police employees will be stationed within their territory. This current structure will change with the police centralization and amalgamation of regional police authorities. 


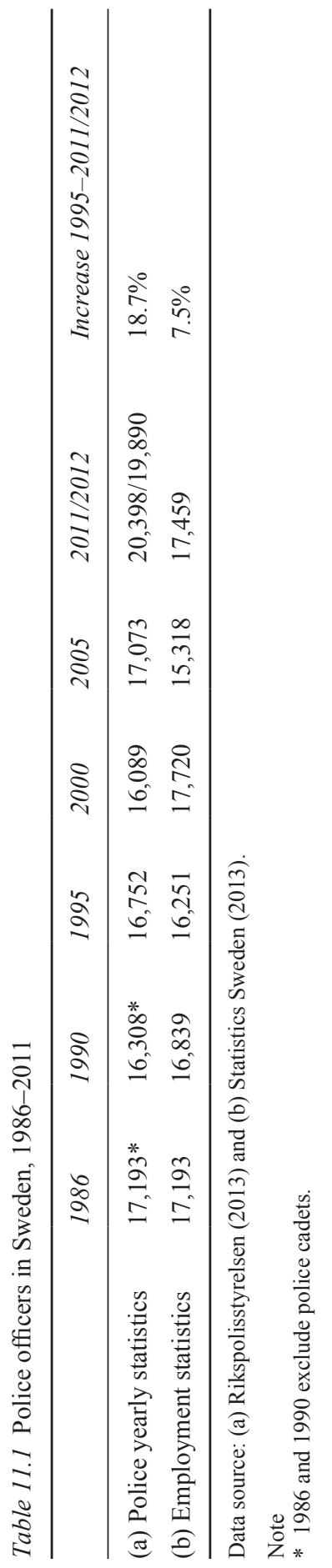


Having a more gender-balanced police force is also part of the national goals. For instance, in 2005, women constituted 22 percent of police officers, while six years later the percentage reached 30 percent. In the late 1950s, Sweden got its first female police. Women's participation as police officers was controversial. Furuhagen (2009) suggests that at that time there were two camps: one camp felt that women meant strength for Swedish police, that both men and women could be police officers; the second camp thought that women were not suitable for practical police service. These women were called "police sisters" and had specific tasks concerning women and children. Police sisters constituted a very small percentage of the country's police force. Initially there were 26 police sisters and more than 6,000 male officers and most police sisters were based in Stockholm. The police sister designation was taken away when the same service levels and the same working conditions began to apply to both women and men. In theory, female police officers received the same training as men, but in practice there were still some differences, especially those related to weaponry and physical training. Not until the 1960s were all positions open to women. Before that, some positions were limited to male applicants.

Although the number of police officers employed reflects the degree of urbanization in Sweden (Stockholm, Västra Götaland, and Skåne, where Stockholm, Gothenburg, and Malmö - the three largest cities - are located), the increase in police officers employed was fairly even between urban and rural counties, at about 20 percent. If these statistics are broken down into smaller geographical units (counties), one notices that the largest increase in police force between 2000 and 2012 occurred in counties neighboring the two most urbanized counties (Malmö and Stockholm): Halland and Uppsala, with 53.5 percent and 40.1 percent, respectively (Figure 11.1).

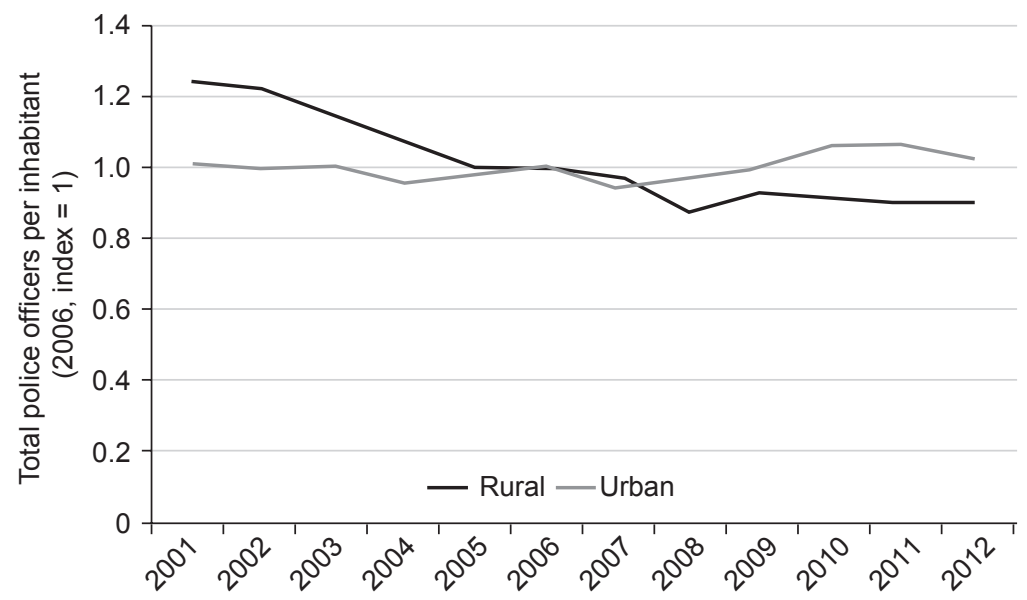

Figure 11.1 Number of police officers in rural and other municipalities, 2001-2012 (source: Lindström, 2014). 
There has been a decrease in police manpower in small and rural areas in relation to urban municipalities (Figure 11.1). Lindström (2014) shows that police manpower in Sweden increased about 15 percent, but rural and small communities have not gained in police numbers since 2006, some communities even experiencing a decrease. For instance, in 2012 about one-quarter of all Swedish municipalities had no permanent police staff. These municipalities often receive police support from officers stationed in nearby municipalities. Moreover, the number of municipalities in Sweden without permanent police staff has steadily increased over time. Does an uneven distribution of police officers affect crime levels?

Lindström (2014) indicates that fewer police has meant an increase in certain types of crimes (and the opposite: relatively less crime in well-staffed municipalities). More interesting is that although crime in general has been lower in rural and smaller municipalities, increases in crime in these areas have been as large as or larger than the increases in urban municipalities. The message that emerges from this study is that the police need to be present in order to help prevent crime. However, the author calls for resident involvement in policing, because police officers are not able to do much about crime by themselves if residents are not actively involved in preventing it.

\section{Partnerships in rural community safety}

This section is divided into two. The first subsection is devoted to local crime prevention groups or councils. In 2012, there were about 300 crime prevention (CP) groups across Sweden. The role of the police is discussed here, as is the role of CP groups in rural areas. CP groups have been the main coordinators of community policing in Sweden since the mid-1990s. The second subsection discusses the expansion of the private security sector within the governance of safety in rural areas. The focus is on the increase in security private companies, either as part of public patrol or direct work with situational crime prevention. Several examples are provided in both sections to illustrate these developments.

\section{Police and local crime prevention councils}

In 2005, the Swedish National Council for Crime Prevention (BR $\AA$ ) performed the most comprehensive evaluation of $\mathrm{CP}$ work at the municipal level up to that time (BRA, 2005). The objective of the study was to investigate how CP groups had developed since the implementation of Allas vairt ansvar, the national CP program in 1996, which was intended to create CP groups throughout the country and support the activities of those that already existed. At that time, BRA found that CP groups were often directly placed under municipal councils, and, together with the police, municipal representatives had the strongest influence in the council's work. Leaders of CP groups devoted on average less than one day per week to $\mathrm{CP}$ activities, which were often financed by the municipality. CP members saw themselves as having a holistic perspective on what happens in the community in terms of crime and safety. 
In a later study, BR $\AA$ indicated that the role of the police was particularly important in smaller rural municipalities (BR $\AA$, 2006). Yet small municipalities had little chance to succeed in $\mathrm{CP}$ work compared to larger urban centers, mainly because of a lack of financial resources and support. It was also found that more experienced $\mathrm{CP}$ groups tended to work better than new ones. The experienced ones had earmarked resources and clear-cut goals. They also actively sought and used knowledge and evidence more often than other $\mathrm{CP}$ groups. The majority of $\mathrm{CP}$ groups focused on youth preventive measures against alcohol and drug addiction.

To follow up these assessments (BRÅ, 2005, 2006), this subsection reviews an analysis performed by the author in cooperation with the criminologist Lars Dolmén and published by the European Journal of Criminology (Ceccato \& Dolmén, 2013). This subsection summarizes the discussion of the role of police in relation to CP groups' actions, organization, cooperation, evaluations, and challenges. The data was gathered using a semi-structured interview with members of local CP councils in eight rural municipalities in Sweden (for more details about the selection of these areas in previous chapters). The template for the interview constituted more than 40 questions divided into five sections. A minimum of five to a maximum of seven persons were interviewed in each municipality, in a total of 49 interviews. To obtain a comprehensive picture of $\mathrm{CP}$ experiences in rural areas in Sweden, data from other sources was obtained, from a database of $\mathrm{CP}$ projects receiving funding from the National Crime Prevention Council and from answers to an email survey to all representatives of local CP groups in Sweden (from a short email "scenario" survey submitted to all representatives of local CP groups, with a 62 percent response rate).

\section{Crime prevention is more than volunteer action}

The composition of CP groups in Swedish rural municipalities was a surprise. It was initially expected that because of strong social ties, CP groups would be composed mostly of volunteers. Contrary to our initial hypothesis, the ideal of eldsjälar (local enthusiasts working voluntarily) as the main drivers of CP work applied perhaps in only one case of the eight studied. Findings show that CP representatives are rarely volunteers and may not always come from existing local social networks. CP members are often employed in different areas of the municipality, police, and/or county council with roles other than $\mathrm{CP}$, devoting a couple of hours per week (or less) to it. CP representatives may not even live in the same municipality as they work in, commuting sometimes on a weekly or daily basis. Their actions are much more institutionalized than was previously thought. This is certainly a development related to how Allas vårt ansvar has affected CP organizations and priorities since the mid-1990s. Thus, CP groups may receive funding for their activities from the municipality or by applying for external funding from regional or national sources or the European Union.

The institutionalization of CP groups may have also impacted how representatives define their CP efforts. When CP representatives were asked about their definition of "Crime prevention," they thought of a "multidimensional construct," 
often reflecting what they do in $\mathrm{CP}$ work. For instance, $\mathrm{CP}$ representatives from local police enforcement define CP based on the traditional role of the police (tackle crime and ensure order) but also reflecting the importance of formal social control, trust, and social networks against criminal events that take place in public places:

$\mathrm{CP}$ is ... to prevent crime, reduce crime curve so the police will get a good reputation and the public has confidence in us.

(Police inspector, south, high crime, old economy)

$\mathrm{CP}$ is about social control. It is by far the best crime prevention effect that we have in the small community, everybody knows everybody.

(Police inspector, south, low crime, old economy)

As is shown in Chapters 13 and 14, people working with youngsters with problems and/or domestic violence tend to see CP's "therapeutic" function for the community in places where violence can be a problem to be tackled in $\mathrm{CP}$ work:

Successful crime prevention is about limiting alcohol to young people, finding alternatives, getting parents more involved. It's a little different culture up here in the North.

(Healthcare advisor, north, low crime, new economy)

Things happen (domestic violence) even in small municipalities. They have to be discussed. When necessary, we must act!

(Crime victims association, north, low crime, old economy)

\section{The work of CP groups in rural areas: are rural issues demoted?}

On a daily basis, CP tackles problems of perceived safety, often relying on safety and night and security walks, involving the local community in general. Through partnerships with schools, CP members may be involved in programs aimed at integrating refugee children who come to these municipalities. Farm crimes (e.g., theft of trucks, fertilizers, cattle) and environmental and wildlife crime do not belong on the main agenda (see Chapter 13). Jones and Phipps (2012) and other British researchers quoted in their article found similar results. As initially expected, CP groups concentrate their work on problems of the "urban core" of the rural municipality and therefore rarely focus on environmental crime, with very few exceptions.

Youth is unanimously the most important issue in rural areas for $\mathrm{CP}$ councils, according to representatives (this topic will be further discussed in Chapter 13). All eight municipalities highlighted the problems of alcohol and drug addiction as well as related problems, some being seasonal and associated with violence in the public and private spheres, vandalism, and, to a lesser extent, property crimes. 


\section{Sweden: policing and crime prevention}

Though youth-related problems may be found in the most remote rural areas in Sweden, they are often taken as a typical big-city problem. The focus on "big city problems" in CP work in rural areas is also found when looking at the projects nationally funded. Why is this so? Partnerships have been central in the national CP model that tends to prioritize urban problems. As an example, the majority of projects funded by BR $\AA$ are in urban areas, and if they are based in rural municipalities, they still focus on issues that are more often found in large cities, such as youth violence, preventive measures against drug and alcohol addiction, or situation-based solutions to improve perceived safety. This is not specific to Sweden. In the United Kingdom, Gilling (2011) suggests that recent developments in national crime governance and policing have by default negated rural crime. In the British case, this is because the new risk-based strategies preclude many rural crime issues from meeting the nationally defined "crime problem" benchmark. The author suggests that until relatively recently, responding to "headline" crime occurring in more populous areas has the priority in performance terms (Gilling, 2007). In Sweden, this might also be the case, but certainly this biased model also reflects a national top-down model of CP that identifies several target areas and establishes frameworks for action often focused on big cities' problems, disregarding rural diversity. This is further reinforced by a scheme of prizes awarded to CP projects assessed as "best practices" following these guidelines, which may be replicated in other municipalities. Whether they make sense in a (different) rural context is difficult to say, but it seems reasonable to expect that there is a need to re-examine the current model. Even if the causes of crime in rural areas are the same as those in urban areas, it seems in-depth knowledge is necessary to tackle problems that are expressed differently depending on where they occur, as crime and perceived safety might depend on context.

\section{Partnerships, knowledge, and resources}

Several interviewees suggested that a large share of their activity is devoted to achieving a satisfactory local partnership per se, as community policing is supposed to be based on information sharing (Figure 11.2). In practice, this means a large part of their time goes into taking courses on crime prevention to improve knowledge among CP representatives and attending lectures and meetings. This has become the main goal of some $\mathrm{CP}$ groups, which is problematic, of course, because partnership and collaborative work, as submitted here, are a means to help CP work, not the end itself. Such work should lead representatives to better understanding of the problems and causes with which they must deal, and which interventions should be put into practice.

Most CP representatives declared good internal collaborative work, but not all did so. Some groups show signs of a sectoral split between those who work with social CP, often with more long-term strategies, and those who work with situational crime initiatives. Overall, community policing seems to be facilitated by strong social ties in rural communities. Some suggest that being small is an 


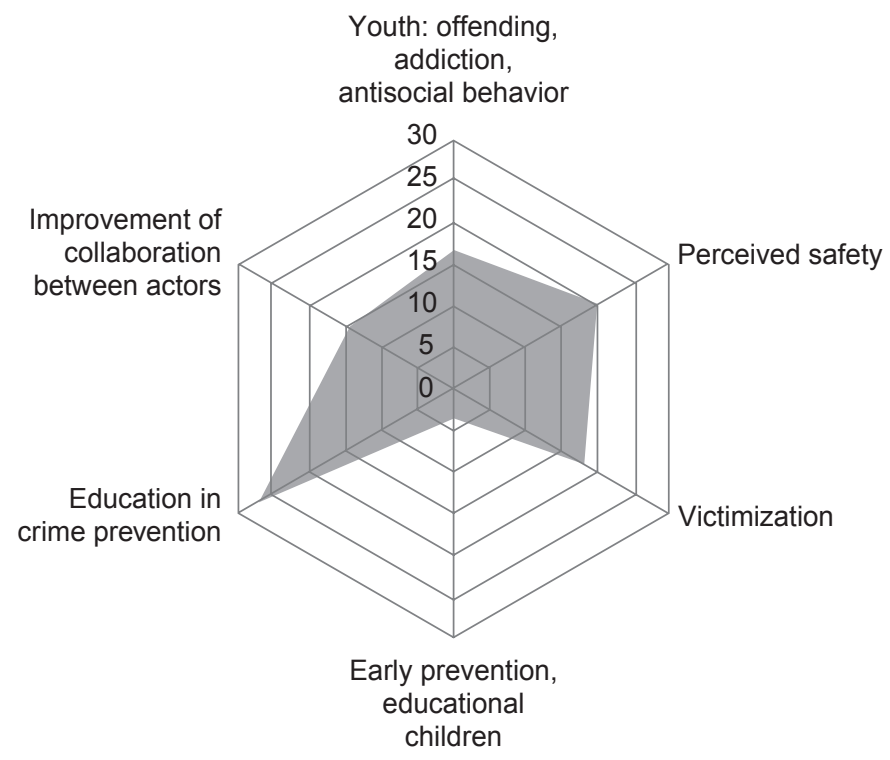

Figure 11.2 Issues addressed by the CP projects financed by BR $\AA$ (\%) (data source: projects granted funding by the Swedish National Council for Crime Prevention (BRA), 2004-2010, in Ceccato and Dolmén, 2013, p. 101).

advantage, because a "problem" can be solved quickly since "unofficial talks" may become "official" just because "one happens to run into someone else." This is perceived to be an advantage by most but not all respondents. What may be an advantage in community policing can be perceived as a sign of unbalanced power relations that, in a small community, may lead to exclusionary practices (see e.g., Yarwood, 2010). These strong social ties may be a hinder for CP work when conflicts between safety and economic goals become a fact. The police inspector quoted below illustrates this case:

I can think it is a disadvantage at times that those who have control over the money also "sit on" the CP council. If you take the economic point of view instead of the CP one, you may "sit on two chairs."

(Police inspector, south, low crime, old economy)

Not surprisingly, the police have been an essential part of the projects which got support from BR $\AA$ during 2004-2010. A brief analysis of these partnerships shows that they tended to be headed either by local or regional police forces or members of the municipal councils themselves, while other $\mathrm{CP}$ actors formally have a more auxiliary role. Figure 11.2 shows that improving collaboration between $\mathrm{CP}$ partners is often a reason for requesting external funding. An obvious source of funding is BRÅ. 


\section{Sweden: policing and crime prevention}

Collaboration within $\mathrm{CP}$ work is not only limited by funding. Interviewees suggested that regulations regarding data secrecy and handling within the organization and between partners, although necessary, is a major hindrance to $\mathrm{CP}$ work. For instance, police officers may have access to individual data on suspects that cannot be shared with those in the CP group. Some suggest that the confidentiality regulations are misunderstood or misused. Particularly in rural areas where "everybody knows everybody," individual information can become a sensitive matter. This becomes more complicated when CP members in neighboring municipalities cooperate (often within their own field).

\section{Assessment of CP groups' initiatives}

Most of the CP projects do not include any precise follow-up, which makes difficult any pre- or post-assessment of the implemented crime prevention measures. Figure 11.3 illustrates that this is the case for the sample of projects financed by BR $\AA$ between 2004-2010. About half of the CP groups performed some kind of evaluation of their activities, and one-third had an action plan. Many collaborated with neighboring CP groups, but only a few had established cooperation with universities, creating a poor knowledge basis for action and assessment. Poor assessment routines characterize $\mathrm{CP}$ work in rural municipalities in Sweden.

Swedish rural CP groups are not alone. The assessment of CP actions in rural areas follows the overall international trend in CP. As suggested by previous research, knowledge about which $\mathrm{CP}$ interventions work and which do not work

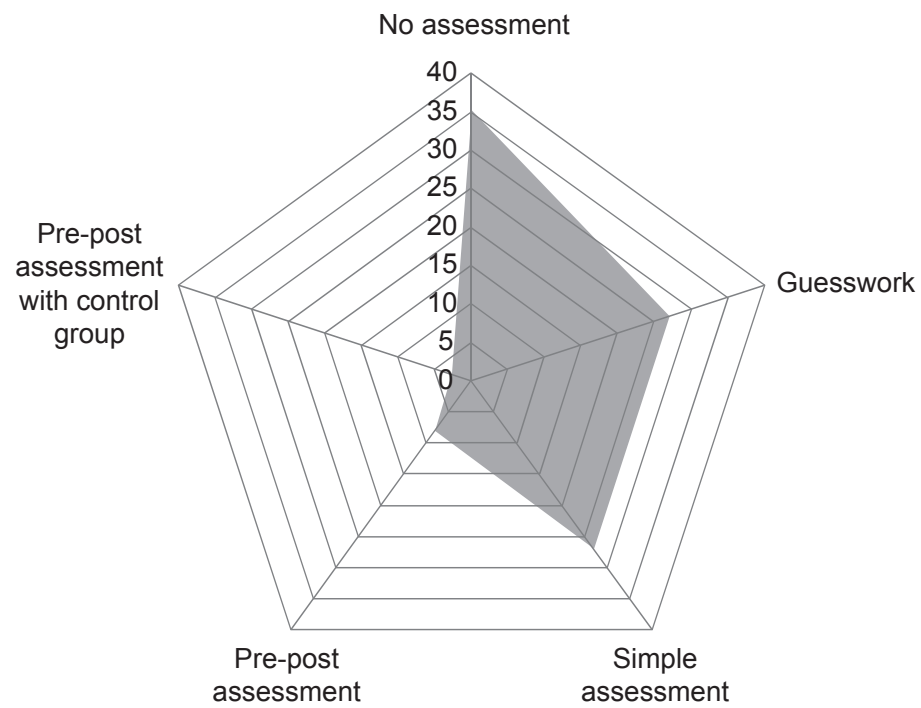

Figure 11.3 Type of evaluation in CP projects financed by BRA (\%) (data source: projects granted funding by the Swedish National Council for Crime Prevention (BRÅ), 2004-2010, in Ceccato and Dolmén, 2013, p. 101). 
remains fragmentary and patchy, even in other contexts than the rural (Wikström, 2007). In Sweden, CP initiatives in rural municipalities may never be assessed to the same extent as those in urban areas because of limited funding in the first place. Moreover, as suggested by Bullock and Ekblom (2010), the problem of assessment of $\mathrm{CP}$ actions may suffer from the fact that they do not always contain the right information to help practitioners select and replicate projects to their own context. There are exceptions, though. Several CP initiatives have been replicated as examples of good practices. The Kroneberg model and EFFEKT, for instance, have been associated with a long-term assessment showing the particular impact of these CP programs both nationally and internationally. These examples are discussed in detail in Chapter 13.

Although most CP groups declare that they make use of crime statistics or other equivalent relevant information, a small proportion of their work is declared to be evidence based. Lack of skills among those involved in CP work seems to be the root of the problem of poor assessment - from the conception stage, to actions and evaluation. Recall that a significant amount of CP activity relates to individuals' own training (Figure 11.2). CP groups tend to keep initiatives that have already been in place elsewhere and are well accepted by the community (e.g., youth recreation centers). When CPs are innovative, they tend to invest in projects that were applied elsewhere (e.g., safety walks, drinking limitations) by importing models and assuming they are "good practice."

\section{Joint police and customs station: an example from Ydre}

The range of basic services offered in rural areas in Sweden has been significantly reduced in the past 20 years. This trend accelerated in the 2000s, and in many parts of the country the degradation of basic services has reached such a level that the basic functions of society are being called into question (Degerlund, Jansson, \& Lönnqvist, 2010). Sweden is not alone in this development. In the United Kingdom, for instance, the rationalization of public services has been keenly felt by those in rural areas, as crime rates have risen in supposedly "crime-free" areas and policing has become less visible (Jones \& Phipps, 2012).

What is interesting is that at the same time that basic services have been shut down, new forms of service provision have been put into place. The example discussed in this section illustrates how the process of amalgamation of the police and customs authorities in the rural municipality of Ydre suggests that both policing and customs services have improved.

Ydre Municipality is in Östergötland County, in southeast Sweden. For the past 10 years, a joint office has been located in Ydre. It currently consists of 10 employees: four employed by the customs authority, five by the police, and one shared (receptionist). In the early 1990s, the Ydre police had only two police employees and could stay open only two hours each week. In Flötningen, a few miles from Ydre, there was a customs station (especially for the Norwegian border) that had been open for clearance of goods for business hours every weekday. By moving the customs station to Ydre and co-locating the two 
authorities, the hours were extended, and services to citizens improved. One bonus of the relocation was that it led to cooperation between customs and police in external services to an extent that had not happened before. Collaboration consists of joint patrol operations when possible, depending on the mission. They may involve drug issues, crime prevention, monitoring of hunting and fishing issues, control of dangerous goods, passport and immigration controls, and customs and traffic controls. They assist each other whenever possible to provide service to citizens. The cooperative agreement is periodically updated when changes in each organization make it necessary.

Of course, expenses are lower with the same office, as we can split the costs, but the best thing about the partnership is that we are now cooperating with the police. This has resulted in a number of successful initiatives.

(Customs representative in Ydre: Schmidt, 2013)

The co-location makes it easy to exchange information, which is important. The result of collaboration between authorities on police matters has yielded excellent results a number of times, such as when several church burglaries were cleared up following a joint operation. The assessment by the authorities is that these crimes would have been difficult to clear up if not for the cooperation between the authorities (Brandt \& Westholm, 2008).

\section{The volunteer sector in policing}

In Sweden, as previously suggested, volunteer work appears to account for a minor portion of direct $\mathrm{CP}$ efforts. Members of $\mathrm{CP}$ groups are often employed in different areas of the municipality, police, and/or county council, having roles other than $\mathrm{CP}$ and devoting a couple of hours per week (or less) to it. However, it is submitted here that this is only a partial view of rural communities that are based to a large extent on complex networks of social relationships linked through local social associations, interest groups, and support groups. Thus, there is a need for a nuanced perspective on volunteer work in rural areas, one that stretches beyond - perhaps not too far - the traditional work of police and $\mathrm{CP}$ groups. For instance, close to the work of police are active support groups such as those working with homeless and missing people, discussed below.

In the United Kingdom, a better understanding of the work done by volunteer groups together with the police has been achieved by Parr, Stevenson, Fyfe, and Woolnough (2012). Six varied cases were selected for in-depth examination, to understand how police resources are deployed and the decision-making processes within police organizations and to focus on what spatial assumptions are made and acted upon during missing events. Missing people represent a significant challenge for the police due to the volume of cases and the potential risks missing people face. A recent study in the United Kingdom looked at numerous cases to add to the knowledge-base about missing person behavior but also to support the best approaches when dealing with missing persons operationally. 
Yarwood (2014) considers searches for missing people one aspect of rural policing. The author illustrates how a search for a person relies on a relationship network that has wider significance than existing formal networks. Concentrating on search dogs, attention is given to the ways that non-human agencies are enrolled in policing networks. This not only broadens understanding of policing but also contributes to the wider debate in rural studies. The author suggests that community-based policing in rural places must similarly recognize how it is linked to wider networks and work in relation to them.

In Sweden, volunteers organized to search for missing persons are not a new phenomenon but could be considered a recent trend when considered as an organized movement under the national group Missing People. When Missing People Sweden formed in 2012, it was a small group of volunteers. Nowadays, Missing People is a popular movement with thousands of volunteers across the country. After solving several cases, the organization has been honored with police medals and important sponsorships. Yet not much in-depth study has been done to understand their methods and how they can be coupled with traditional community policing.

Another stream of volunteer work that has increased in Sweden revolves around those who live as homeless. The media has shown examples of a split debate between groups who favor support to the homeless and those opposed. The homeless are often associated with mendicancy in the streets and often considered a problem of "social order" in large cities, particularly in public places such as at train stations and bus stops. Even in big cities, direct conflict between locals and people found in the street are reported in national newspapers (Sundberg, 2014). For instance, a man accused of assault by several witnesses has himself brought charges against a woman for assault. He shoved her away because he felt he was under attack. The local police officer declares she has never experienced anything like it during her years on duty. This is seen as a counter-reaction to a dramatic increase in homeless EU migrants that often turn to mendicancy to survive.

On a positive note, people are not waiting for formal volunteer organizations to help. Some support is being provided by individuals themselves (see for instance, Hökerberg, 2014). A recent report by Stadsmission (2014) indicates almost half of homeless mendicants sleep outdoors. The majority state that they live in homelessness in their home country. Because of the way Swedish social services interpret current regulations, help is mostly offered by churches and volunteer organizations, sometimes in cooperation with municipalities. This includes practical assistance with food, clothes, and somewhere to sleep, but also information, advisory services, language instruction, and schooling for their children. Homeless EU citizens present their own range of problems, having different difficulties and needs (Socialstyrelsen, 2013). The number of homeless people is greatest in urban areas (this applies particularly to EU migrants and non-EU citizens who have lived in an EU member state as long-term residents and therefore have rights similar to those of EU citizens), but homelessness is also found in rural areas. 


\section{Policing and the expansion of private security companies}

Private security companies provide services for private enterprises, government bodies and municipalities, and individuals. Private security is not a new phenomenon, nor has its expansion gone unnoticed, but they have taken over several responsibilities that in the past were associated with the public sector. As the presence and impact of commercial security actors increases, the roles and functions conventionally ascribed to the state are being transformed as new geographies of power and influence take form (Berndtsson \& Stern, 2011). As we shall see below, rural policing is no exception.

Private guards have become an ordinary part of the landscape as they go almost unnoticed. Their presence has become part of everyday life in public places (Button, 2007). In Sweden, the number of private security companies increased 161 percent between 1993 and 2013 (Figure 11.4). Although most private security companies in Sweden are found in the regions containing the three largest urban areas (Stockholm, Gothenburg, and Malmö), there has been a significant increase in the number of private security companies in smaller municipalities, particularly in a few counties such as Kronoberg, Kalmar, Götaland, Halland, and Norrbotten, in northern Sweden.

Apart from the increase in the number of private security companies in Stockholm, Skåne, and Västra Götaland, the private security sector has expanded substantially in counties such as Halland, Kronoberg, and Gotland, counties that have also experienced a relatively sharp increase in police officers (Figure 11.5a and 11.5b). This simultaneous increase is difficult to explain at this aggregate level, but as police officer assignment is often a function of crime rates and

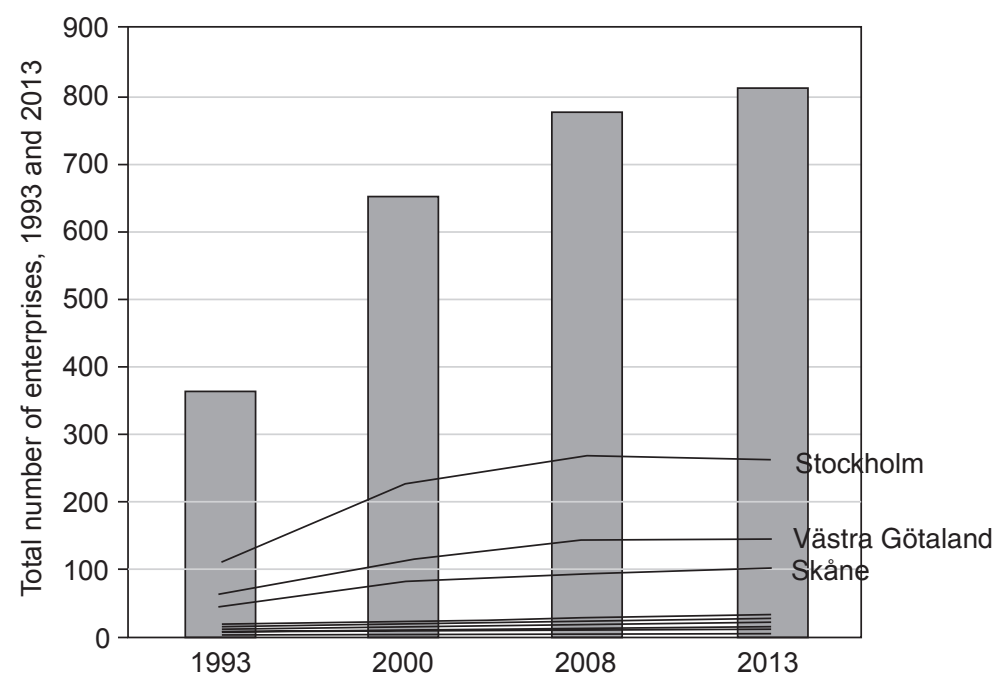

Figure 11.4 Number of enterprises in the security sector between 1993 and 2013, Sweden (bar) and by county (lines) (data source: Statistics Sweden, 2013). 


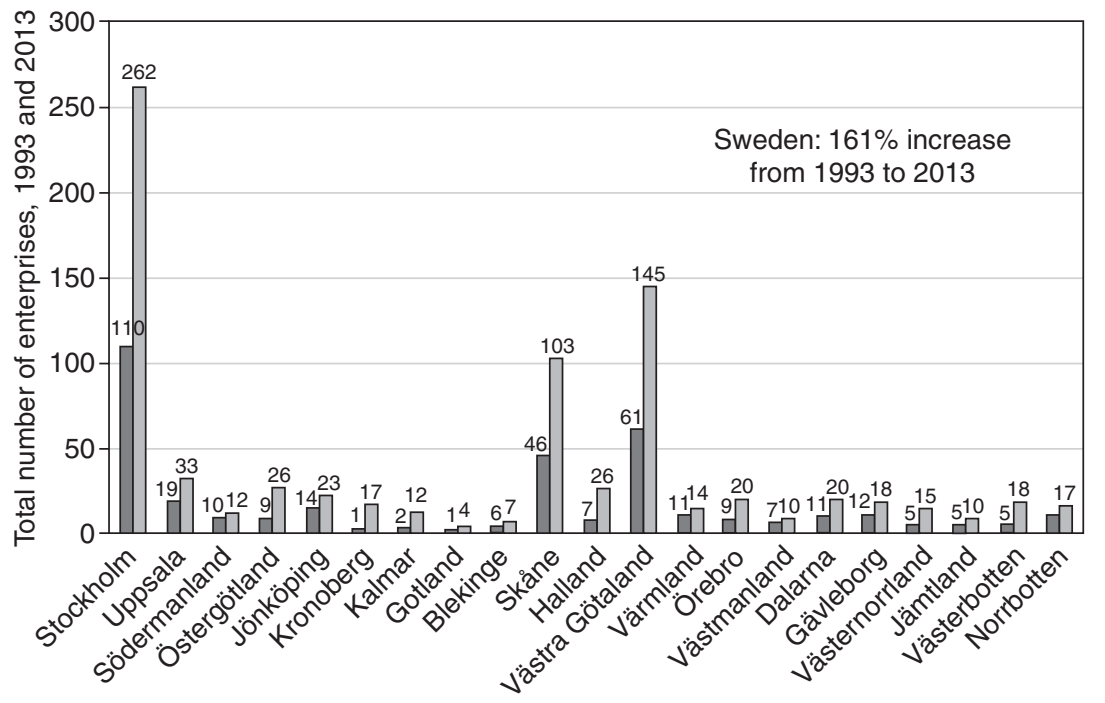

(a)

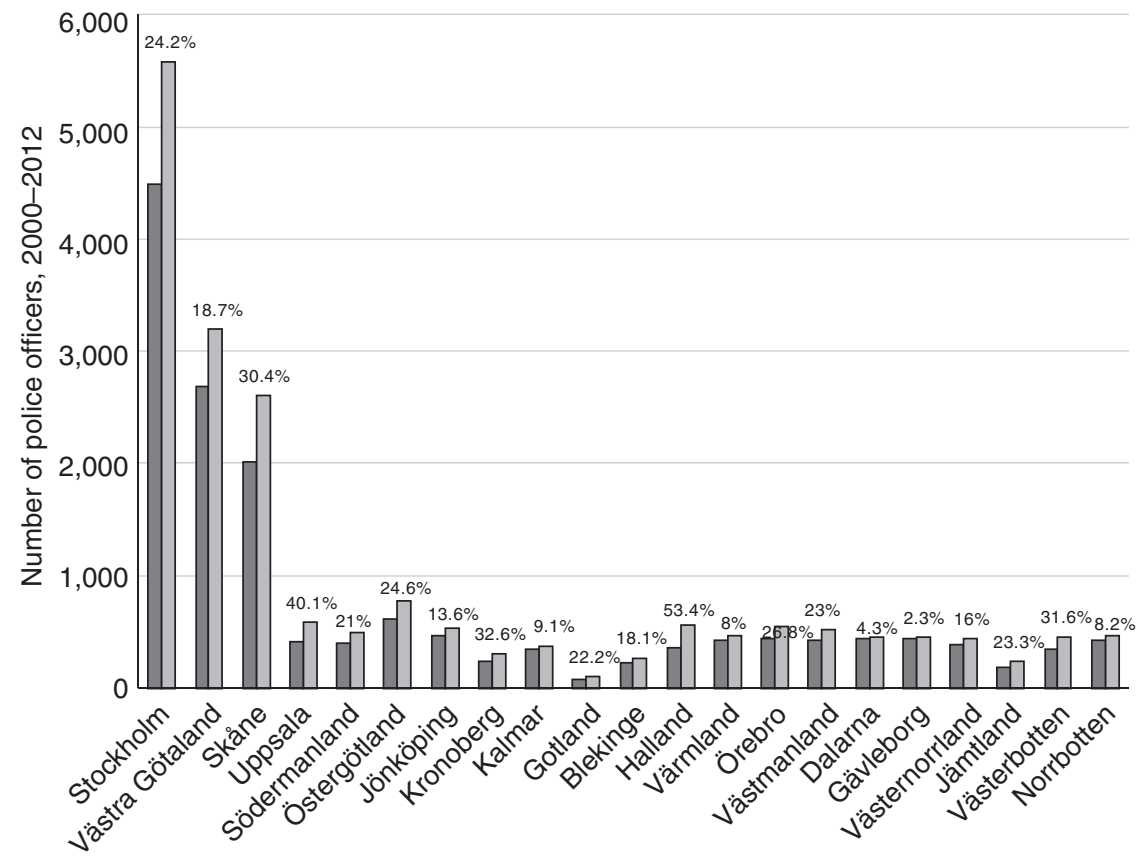

(b)

Figure 11.5 (a) Number of enterprises in security sector by county, 1993 and 2013, and (b) number of police officers and increase (\%), 2000-2012 by county (data source: (a) Statistics Sweden, 2013; (b) Swedish National Police Agency, 2013). 
demography in an area, the increase in the private security sector may reflect an increase in criminogenic conditions in the area. Alternatively, the increase in the private security sector could reflect a set of priorities that are set at regional and local levels that may not be linked to a crime increase per se.

\section{Police and private security company in Söderköping}

Söderköping is an example of a municipality in which the private sector has become integral to policing and safety governance. The municipality has the police and a private security company that combats and prevents crime. The County of Östergötland, where Söderköping is located, has experienced an increase in police officers of about 25 percent of the total and a rise of almost 200 percent in the number of enterprises in the security sector during the past decade (Figure 11.5a and 11.5b).

Key actors in the security partnership for this rural municipality perceive their roles as safety service providers differently and are accepted by the local community in different ways. The private company in this case is run by a former police officer. The company directly provides services to increase safety and security, with staff that walk around in the municipality and talk to young people - primarily and traditionally a job for the police. The company's work is intertwined with work developed by the local CP group. As shown below, people continue to expect the police to be more visible even though they believe the police are not as efficient as the private security companies. The municipality is a typical middle-sized town with burglaries, thef, and vandalism accounting for most victimization. This example questions how the lines of distinction between the public and the private are challenged by the needs of rural communities.

A survey conducted by Lundin (2006) shows that the majority of respondents had not seen the police at all recently and were dissatisfied with police work, particularly those outside the urban core. Responses included, "What cop?" and "Söderköping has no police." Many stated that they had never seen any police in Söderköping. "Yes, sure there is a police officer, but they're probably just here sometimes?" As a result, as many as 75 percent of respondents declared not being satisfied with the police presence, 52 of the respondents were dissatisfied with the way the police prevent crime, and 40 percent of respondents felt private security was needed in the area where they live.

In rural areas, the dissatisfaction with the police seemed greater, as only 18 percent of respondents declared satisfaction with how the police work against crime; almost the same proportion is pleased with the police presence. However, a higher proportion of respondents in the outer areas than in the urban area preferred not to comment on police actions. A few respondents were concerned whether the police would actually make it to the crime scene if something happened. Statements that have emerged during the interviews in the outer areas were that the police were not as visible as they would expect, the police were under-resourced and should be working in a more preventive way (Lundin, 2006). 
Hiring private security companies is seen by a share of the interviewees as a reasonable solution to prevent crime (theft, burglary, and vandalism), as the police are not as present as they would expect. However, this opinion was not shared by all; it depended on place of residence. For instance, in the Broby-Norra district, two-thirds of respondents saw no need for a security company, as the area was a quiet area, or they believed that security companies should not perform police tasks. In another part of Söderköping, in Eriksvik-Södra, respondents had a more positive view of private security companies: half of respondents saw a need for a private security company as a way to increase perceived safety and deter crime. According to them, the private security company seemed more reliable, as the police have limited resources. The "efficiency" and "reliability" of the private security sector has already been noted in the literature as one reason for its expansion at the expense of the police in fighting crime and ensuring community safety (Berndtsson \& Stern, 2011; Loader \& Walker, 2007). However, the type of work done by security companies in Söderköping and/or other rural municipalities is not generally well known, nor is it known whether their activities are submitted to any type of supervision or, in that case, by which authorities.

It can no longer be expected for security to be provided or controlled by either public or private actors anymore. If this was the case, this assumption would be an oversimplification of the current policing model in rural areas that obfuscates an existing interplay between private security companies and the police. If policing is performed in other rural municipalities in the same way as it is done in Söderköping, the role of public (police) and private (security companies) actors would not be so easily separated. However, neither this fact nor the lack of police resources - a common excuse for hiring private companies - contribute to improve the private sector legitimacy as key actors in ensuring security to those living in rural areas.

With the imminent police centralization in Sweden, a new community policing model has to be in place to accommodate the current expansion of the private security sector. The challenge is how to ensure that security remains a public good once private sector security providers have established themselves. First, the role of private security companies, either as patrols or engaged in crime prevention work, has to become more transparent. Private security companies have become arms of the state by developing their role as guarantor of security as a public good (Loader and Walker, 2007). Second, the engagement of private security companies should happen in a wider context of community policing, in which CP groups play a central role as coordinating bodies together with the police. Epstein (2007, p. 150) suggests that the state governs through private security actors, but is that so in rural areas? Third, the commodification of security involves a large number of actors beyond private security companies. In rural areas, they may take different forms (e.g., security technology companies, security networks), so obtaining a better understanding of the private sector as security provider is desirable in both rural and urban contexts.

Chapter 13 returns to the case of Söderköping to illustrate the layers of social control that exist to tackle vandalism and to provide details about residents' satisfaction with the police and private security companies. 


\section{Private security networks and policing}

Private security networks offer an alternative way of reporting crime and promoting remote surveillance. The system is separate from the emergency telephone number or other standard methods of contacting police that allows a member of the community to supposedly provide anonymous information about criminal activity. The network is funded by members of the network, such as trucking companies, forest contractors, excavation contractors, retailers, and homeowners. In Sweden, there is also a company specialized in situational crime prevention in several different areas but heavily focused on issues that rural areas suffer most: crime against transport and vehicles (goods), building companies, and homeowners.

The private network is devoted to crime against vehicles and goods. The company supports a network using different forms of preventive initiatives. Thousands of people are said to be active in crime prevention, as more than 4,000 vehicles are connected to the network through an app that can be used to report crime, serve as remote surveillance, and receive real-time information about crime in progress. As a crime occurs in an area, data is reported to the network of members. The system works with informal reporting of events as they occur either by testing or sending images linked to $x-y$ coordinates. All information sent to the private security network by email or through the app is protected by the Personal Data Act (PDA), ensuring anonymity. Ongoing crimes or information about ongoing crimes must also be submitted to the police. For more details, see Chapter 12, which exemplifies the work done by private security networks to combat diesel theft in remote rural areas in Sweden.

\section{Future of rural policing: what happens with police re-organization?}

On January 1, 2015, 21 police authorities will be merged to form a single national police authority in Sweden (Table 11.2). What will the new police organization mean for policing in rural areas? The reform signals a centralization of the vital functions of the police at the same time as it is intended to keep community policing alive. The model imposes new demands on the current traditions and culture of police work in various sectors and at various geographic levels. As it is now, the 21 police authorities work fairly independently. As such, the lack of standardization makes difficult the daily routines of police work as well as collaboration between authorities. Lindström (2014) also suggests that the police have been severely criticized for not being able to clear up more offenses though their resources have been increased. This is also one reason why the country's 21 police authorities will be consolidated into a single police service by 2015 .

The new police authority is expected to increase consistency and uniformity, promoting clear guidance and control with short decision paths over seven police 
regions. These police regions are planned to have a similar basic structure and organizational units with similar tasks under the same denominations (SOU, 2014). It is expected that this uniformity in the organization will strengthen opportunities to explore similar approaches across police activities. The aim of unifying the organization this way is a more flexible use of resources and thus increased efficiency. At the regional level, analytical entities will investigate crimes that require special skills or are infrequent, such as cybercrime or child pornography. At the local level, knowledge of local communities is crucial for effective police work. The police chief's responsibility is to ensure that there are sufficient police resources in every municipality for police work and in relation to the police's commitments in community policing schemes. This support is expected to ensure that local police authorities can fulfill the commitments made to the local community. To ensure the continued development of crime prevention and community safety, the Police Authority should also allocate resources for these tasks based on key performance indicators. An instrument for this work will be safety surveys that, starting in 2015 , will be conducted in all municipalities (SOU, 2014).

The police reform builds on the previous work and experience acquired since the implementation of local police (närpolisen) in the mid-1990s. About 85 percent of municipalities already have a collaboration agreement with the police (BRA, 2006). The BR $\AA$ report reveals that this agreement is considered to have great potential for successful policing, but in many municipalities there are a number of problems to making it work. Both the police and the municipalities declare that they face difficulties keeping the agreement alive. An important factor for successful collaboration is reportedly to be the existence of a coordinator who can drive collaborative work forward.

From the police side, the current proposals for the police organization are creating anxiety among police employees (SOU, 2014), especially in relation to their role in community policing. For instance, some people suggest that there is a risk that it may provide a pretense, internally and externally, that crime prevention and intervention are two different "boxes" associated with different human resources when in fact these roles will be performed by the same individuals in some parts of Sweden. This is certainly true for the case of rural and small municipalities. This might give rise to unrealistic expectations on the number of police officers in the main office and the number of tasks that can be performed (SOU, 2014).

Rural areas are often associated with strong social links and networks which can be perceived as a resource in policing as well as a hindrance. In this respect, the report by SOU (2014) shows that some police officers in collaborative schemes have been concerned that they may feel that citizens should decide what they should do. There is also a concern that further attachment to the community can be perceived by police officers as an extra workload and generate feelings of inadequacy.

Contrary to the new reform, old challenges are associated with the size of the police forces and remoteness of some parts of the country. For instance, in an 


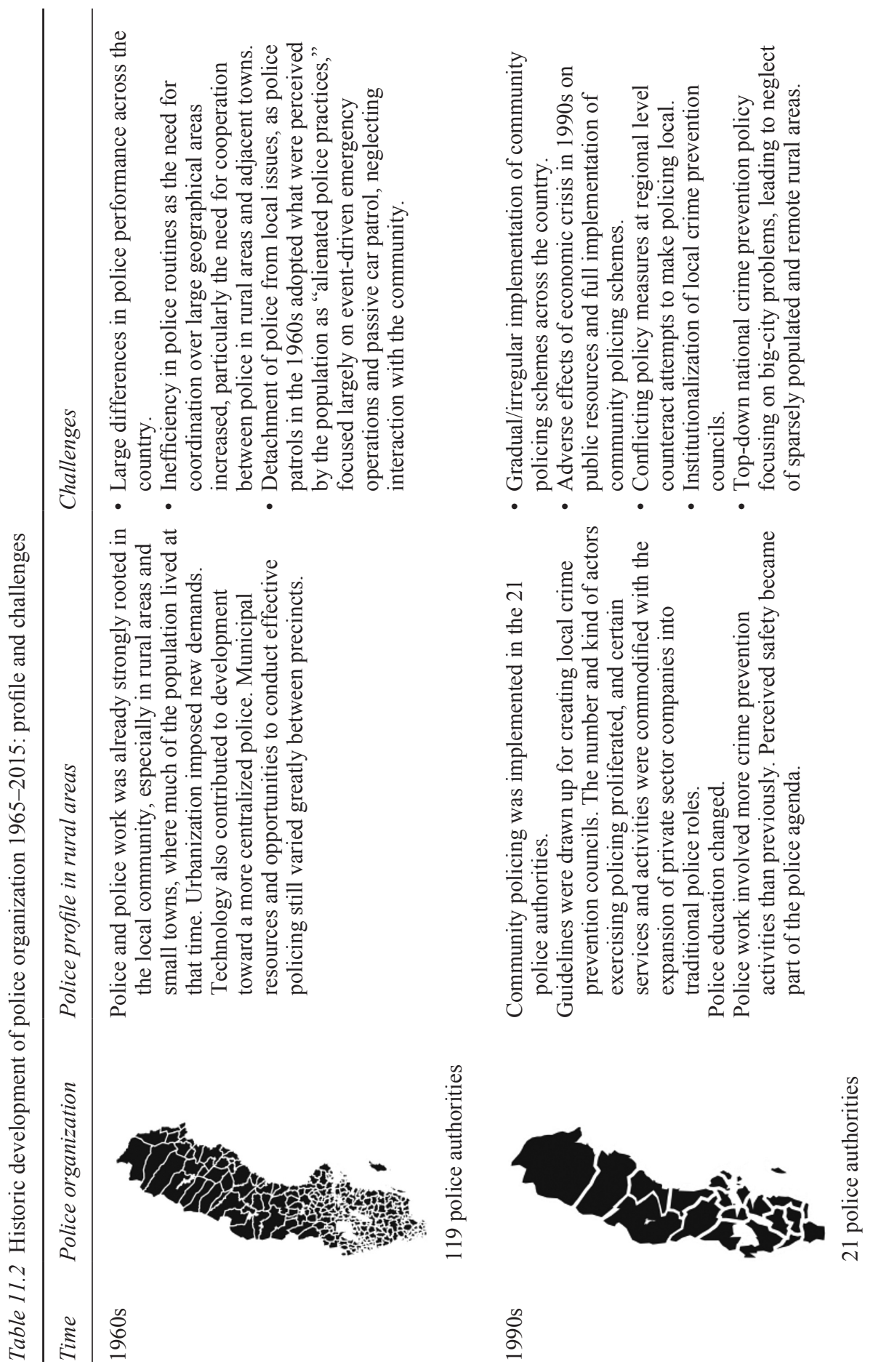



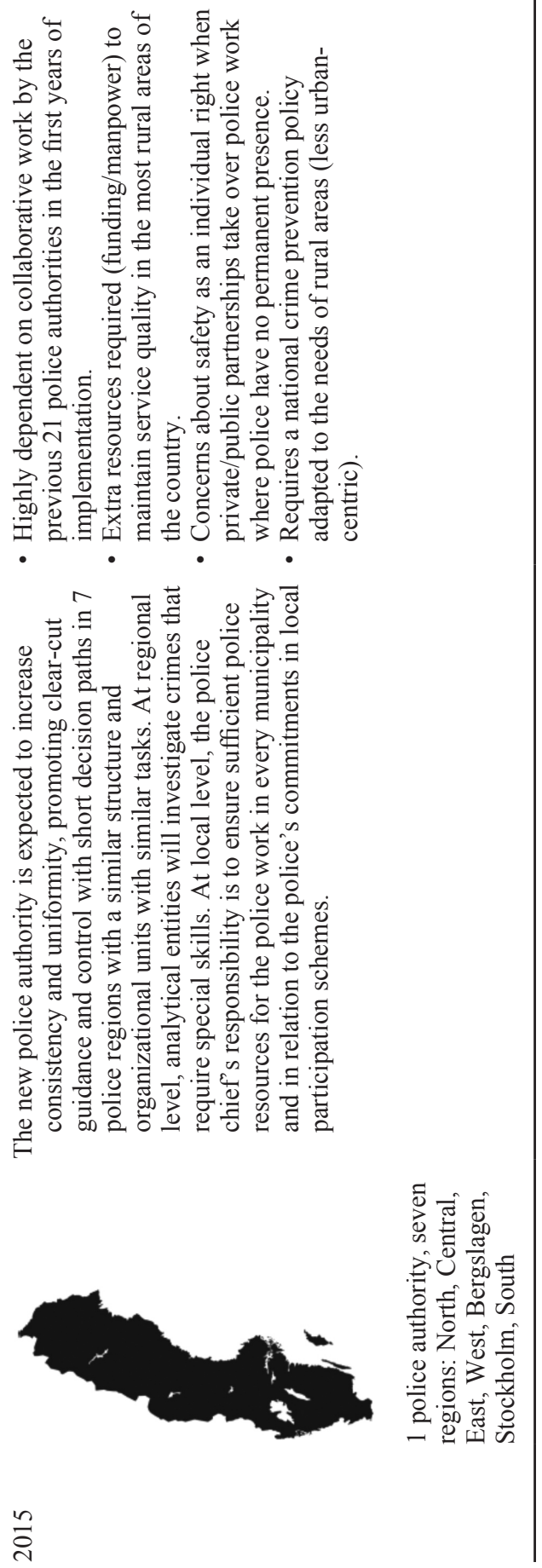
international perspective, Sweden, like the other Scandinavian countries, has relatively few police officers per capita (Lindström, 2014). The same author indicates that as late as 2012 about one-quarter of all municipalities did not have a permanent police staff. Currently, these communities receive police support from officers stationed in nearby municipalities. Contrary to the political vision, he adds, there has been a steady increase in non-permanent policed municipalities in Sweden since the 2000s, and they tend to be concentrated in smaller municipalities.

On top of this, the supply of police manpower in rural areas has become a problem in the 2000s. As shown in previous sections of this chapter, the number of police officers in Sweden has increased since 2006, but this increase has been concentrated in larger urban areas, not reaching the rural and small municipalities. In this context, it is worth noting that some municipalities have a surplus of police, whereas others are being under-policed. Still, as shown below, sharing police manpower seems to be the future of dealing with policing challenges in rural areas. Of course, this goes against the principles of community policing as stated in the 2015 police organization:

Ensuring police presence and local support is often a challenge in rural areas.... [A]s regards police intervention, there may be geographic and demographic reasons to deviate from the main principle that the police have to act and have responsibility for the local communities (the lowest geographical level). This may for example be necessary in rural areas where there is a need to share responsibility for emergency intervention - at least during some part of the day.

(SOS, 2012, pp. 12-13)

However, some rural and small municipalities run a higher risk of being underpoliced even with these alternative solutions (such as sharing police manpower between municipalities). Part of patrol work has already been taken over by private security companies. As was shown in previous sections, situational crime prevention is nowadays supported by ICT and active surveillance by residents and passers-by, but the framework for receiving this information has yet to be put in place. For social crime prevention, municipal authorities and social services can carry on the work of preventing crime and delinquency, as is already done, together with schools and individual organizations. How this mix can be used to produce the desirable results in rural areas is still to be seen.

\section{Concluding remarks}

It is unclear to what extent policing reform in the mid-1990s was fully implemented in accordance with the government's intentions. A good sign is that nowadays there are about 300 community partnerships (crime prevention groups) around the country. They are often composed of a core of representatives from the municipality, police, and schools. This homogeneous format for crime 
prevention was inherited from the traditional decentralized municipal planning system in Sweden but, more importantly, from the structural changes imposed by police reform around local crime prevention. The economic downturn in the 1990s affected public resources and most likely the full implementation of community policing schemes. Top-down national crime prevention policies focusing on big-city problems neglect the special demands of sparsely populated or remote rural areas. For instance, property crimes targeting enterprises, farm crime, environmental and wildlife crime often fall outside a crime prevention group's agenda. Members of crime prevention groups who were interviewed unanimously designated youth issues as the most important in rural areas for crime prevention councils. Most of the work by such groups does not include any strict follow-up. When it does, the evaluation is characterized by simple assessment procedures. Different types of crime prevention models are usually "imported" from other municipalities as examples of good practices. Little thought is put into the adequacy of these remedies in a particular rural context.

With the new police authority coming into force in 2015, it is expected that the consistency and uniformity of routine police work will increase, as the existing 21 police authorities disappear. The centralization of certain functions should make police work more effective and economically viable. The 2015 model also relies on intentions to keep strong links to local policing alive. At the local level, future work will build on experiences with existing local partnerships between the police, municipal authorities, the private sector, and citizens that stem from experiences from community policing reform in the 1990s and onwards.

What are the challenges and opportunities of the new police in rural areas?

With centralization, there is a risk that links to rural (sparse/remote) regions will weaken over time, as permanent police positions decrease in small and rural municipalities $-\mathrm{a}$ trend that has been reinforced in the past decade. The intention to keep community policing strong demands extra resources, in terms of direct funding as well as manpower to maintain the quality of service in the most rural areas of the country. To make community policing more sensitive to the needs of rural areas (e.g., a less urban-centric model), a national crime prevention policy needs to incorporate clear roles for new safety providers, particularly private security companies, volunteers, and other actors in local safety partnerships. The rapid increase in private sector security in small and rural municipalities in the past few decades generates concerns about "safety as an individual right," as private/public partnerships take over the police work when the police are no longer present.

The police reorganization generates a number of opportunities, of course. For instance, at the same time that basic services are closed down, such as a police office, new forms of service provision can be put in place. The example discussed in this chapter illustrates how the process of amalgamation of the police and customs can trigger better services by both. Another opportunity emerging as the police as an authority are no longer present full time is to engage other actors in community policing. This is nothing new, but exemplary volunteer organizations can fill the gap and provide the insurance that the community needs (e.g., successful cases driven by Missing People). In some cases, the 
synergy between these "new actors" and police is said to help strengthen existing social bonds through the creation of hybrid networks of information in rural areas. People living in rural areas need better understanding between themselves and police that will change the image of the police as the only safety provider.

In addition, policing in rural areas has the potential to become more sensitive to continuously changing urban-rural relationships. The incorporation and use of ICT to improve surveillance and crime detection in areas where guardianship is low is an example of such potentiality. In terms of surveillance, the capacity of geo-referencing events by texting, voicing, or imaging as crime happens is new in policing but it is here to stay. The use of social media in community policing may be particularly important in rural areas, because of the long distances, which have traditionally been one of the barriers for police work in rural areas. Still, this transformation will only be possible with a long-term involvement of key actors in community policing, in which the police has a central role.

\section{Note}

1 This section relies heavily on the written work and personal contact with the Swedish criminologist and historian Björn Furuhagen - for a complete reference to his work, see the reference list. This author is grateful for the permission granted by Furuhagen to translate his work, here partially reproduced.

\section{References}

Barclay, E., Scott, J., \& Donnermeyer, J. (2011). Policing the outback: Impacts on integration in an Australian context. In R. Mawby \& R. Yarwood (Eds.), Rural policing and policing the rural: A constable countryside? (pp. 33-44). Farnham: Ashgate.

Berndtsson, J., \& Stern, M. (2011). Private security and the public-private divide: Contested lines of distinction and modes of governance in the Stockholm-Arlanda security assemblage. International Political Sociology, 5(4), 408-425.

Brandt, D., \& Westholm, E. (2008). Statens nya geografi. Stockholm: Högskolan Dalarna.

Brottsförebyggande rådet - BRÅ (National Council of Crime Prevention). (2005). Ett steg på väg. Kartläggning av de lokala brottsförebyggande råden (Vol. 15). Stockholm: BRÅ.

Brottsförebyggande rådet - BRÅ (National Council of Crime Prevention). (2006). Redovisning av uppdraget att analysera vilka samarbets: och arbetsformer som skapar förutsättningar för goda resultat i lokalt brottsförebyggande arbete. Stockholm: BRÅ.

Bullock, K., \& Ekblom, P. (2010). Richness, retrievability and reliability: Issues in a working knowledge base for good practice in crime prevention. European Journal on Criminal Policy and Research, 16(1), 29-47.

Button, M. (2007). Security officers and policing: Powers, culture and control in the governance of public space. Aldershot: Ashgate.

Cain, M. (1973). Society and the policeman's role, London. London: Routledge \& Kegan Paul.

Ceccato, V., \& Dolmén, L. (2011). Crime in rural Sweden. Applied Geography, 31(1), 119-135.

Ceccato, V., \& Dolmén, L. (2013). Crime prevention in rural Sweden. European Journal of Criminology, 10, 89-112. 
Cordner, G., \& Scarborough, K. (1997). Operationalization community policing in rural America: Sense and nonsense. In Q. Thurman \& E. McGarrell (Eds.), Community policing in a rural setting (pp. 11-20). Cincinnati, OH: Anderson Publishing.

Degerlund, B., Jansson, B., \& Lönnqvist, B. (2010). Lokala Hållbara Servicelösningar. Stockholm: Hela Sverige Ska Leva.

Donnermeyer, J., DeKeseredy, W. S., \& Dragiewicz, M. (2011). Policing rural Canada and the United States. In R. Mawby \& R. Yarwood (Eds.), Rural policing and policing the rural: A constable countryside? (pp. 23-32). Farnham: Ashgate.

Epstein, C. (2007). Guilty bodies, productive bodies, destructive bodies: Crossing the biometric borders. International Political Sociology, 1(2), 149-164.

Falcone, D. N., Wells, L. E., \& Weisheit, R. A. (2002). The small-town police department. Policing, 25(2), 371-384.

Fenwick, T., Dockrell, R., Roberts, I., \& Slade, B. (2012). Rural policing: understanding police knowledge and practice in rural communities. Annual Report 2011. Dundee: Scottish Institute for Policing Research.

Furuhagen, B. (2004). Ordning på stan: Polisen i Stockholm 1848-1917. Trelleborg: Brutus Östling.

Furuhagen, B. (2009). Från fjärdingsman till närpolis: en kortfattad svensk polishistoria. Växjö: Växjö universitet Polisutbildningen.

Fyfe, N. R. (1995). Law and order policy and the spaces of citizenship in contemporary Britain. Political Geography, 14(2), 177-189.

Gilling, D. (2007). Crime reduction and community safety: New Labour and the politics of local crime control. Cullompton, Devon: Willan Publishing.

Gilling, D. (2011). Governing crime in rural UK: Risk and representation. In R. I. Mawby $\&$ R. Yarwood (Eds.), Rural policing and policing the rural: A constable countryside? (pp. 69-80). Farnham: Ashgate.

Hökerberg, J. (2014, May 30). Det var som att hitta hem. Dagens Nyheter. Retrieved April 14, 2015, from www.dn.se/sthlm/bienvenido-flores-det-var-som-att-hitta-hem/.

Jones, J., \& Phipps, J. (2012). Policing farm crime in England and Wales. Paper presented at the Papers from the British Criminology Conference, 12, 3-24.

Kommunaktuellt. (2002). Närpolisen i din kommun. Kommunaktuellt, 35-36.

Lindström, P. (2014). Police and crime in rural and small Swedish municipalities. Journal of Rural Studies, doi:10.1016/j.jrurstud.2014.12.004.

Loader, I., \& Walker, N. (2007). Civilizing security. Cambridge: Cambridge University Press.

Lundin, T. (2006). Safety survey in Söderköping (p. 53). Söderköping: Söderköping kommun.

Mawby, R. (2011). Plural policing in rural Britain. In R. Mawby \& R. Yarwood (Eds.), Rural policing and policing the rural: A constable countryside? (pp. 57-67). Farnham: Ashgate.

Mawby, R., \& Yarwood, R. (Eds.). (2011). Rural policing and policing the rural: A constable countryside? Farnham: Ashgate.

Parr, H., Stevenson, O., Fyfe, N., \& Woolnough, P. (2012). Geographies of missing people: Processes, experiences and responses. Scottish Institute for Policing Research: Annual Report (p. 81). Dundee: Scottish Institute for Policing Research.

Payne, B. K., Berg, B. L., \& Sun, I. Y. (2005). Policing in small town America: Dogs, drunks, disorder, and dysfunction. Journal of Criminal Justice, 33(1), 31-41.

Pompa, F., \& Ganier, D. (2013, February 27). In gun debate, it's urban vs. rural. US TODAY. Retrieved April 14, 2015, from www.usatoday.com/story/news/nation/2013/02/27/gunsingrained-in-rural-existence/1949479/. 
Schmidt, N. (2013). De känner sig hotade. Dalarnas Tidning. Retrieved April 17, 2015, from www.dt.se/allmant/dalarna/de-kanner-sig-hotade.

Sjöholm, E. (1941). Lagstiftningen om polisväsendet. Stockholm: Norstedts.

Socialstyrelsen (National Board of Health and Welfare). (2013). Homelessness among EU citizens in Sweden. Stockholm: Socialstyrelsen.

Statens Offentliga Utredningar - SOU. (2012). OP-1 Den lokala polisverksamheten. Stockholm: Genomförandekommittén för nya Polismyndigheten, 16. Retrieved April 17, 2015, from www.polissamordningen.se/.../OP_1_Den_lokala_polisverksamheten.pdf.

Statens Offentliga Utredningar - SOU. (2014). Beslut om huvuddragen i den nya polismyndigheten detaljeorganisation (p. 66). Stockholm: Regeringen.

Stadsmission, S. (2014). Hemlöshetsrapport. Stockholms Stadsmissions hemlöshetsrapport (p. 36). Stockholm: Stadsmission.

Statistics Sweden. (2013). Employment statistics database (code SSYK 3450). Stockholm: SCB.

Sundberg, M. (2014, April 1). Man knuffade ut tiggare i gatan. Dagens Nyheter. Retrieved April 17, 2015, from www.dn.se/nyheter/sverige/man-knuffade-ut-tiggare-i-gatan/.

Rikspolisstyrelsen (Swedish National Police Board). (2013) Police officers in Sweden, 1986 to 2011 [Database]. Stockholm: Rikspolisstyrelsen.

Thelin, K., \& Svantemark, K. (2005). Polis i kris: har kommunerna kraften. Stockholm: Timbro.

Weisheit, R. A., Falcone, D. N., \& Wells, L. E. (2006). Crime and policing in rural and small-town rural America. Prospect Heights, IL: Waveland Press.

Weisheit, R. A., Wells, L. E., \& Falcone, D. N. (1994). Community policing in small town and rural America. Crime and Delinquency, 40(4), 549-567.

Wikström, P.-O. H. (2007). Doing without knowing: Common pitfalls in crime prevention. Crime Prevention Studies, 21, 59-80.

Yarwood, R. (2010). An exclusive countryside? Crime concern, social exclusion and community policing in two English villages. Policing and Society, 20(1), 61-78.

Yarwood, R. (2011). Whose blue line is it anyway? Community policing and partnership working in rural places. In R. Mawby \& R. Yarwood (Eds.), Rural policing and policing the rural: A constable countryside? (pp. 93-105). Farnham: Ashgate.

Yarwood, R. (2014). Lost and found: The hybrid networks of rural policing, missing people and dogs. Journal of Rural Studies, 39, doi:10.1016/j.jrurstud.2014.11.005.

Yarwood, R., \& Edwards, B. (1995). Voluntary action in rural areas: The case of neighbourhood watch. Journal of Rural Studies, 11(4), 447-459. 